\title{
PENYULUHAN MANAJEMEN PENGENDALIAN, PENCEGAHAN KEKERASAN DAN PORNOGRAFI PADA SISWA SMPN 2 TENJO KABUPATEN BOGOR
}

\author{
Lia Asmalah*, Zaenal Abidin, Aden Prawiro Sudarso \\ Dosen Fakultas Ekonomi. Universitas Pamulang \\ Email*:asmalahlia63@gmail.com
}

\begin{abstract}
ABSTRAK
Tulisan ini bertujuan agar siswa-siswi dapat mengendalikan dan menecgah aksi pornografi dengan penyuluhan yang di berikan oleh Dosen-dosen Universitas Pamulang.

Teknik pendekatan dilakukan dengan metode seminar dan tanya jawab secara langsung

Hasil kegiatan ini menjadikan para peserta siswa -siswi SMPN 2 Tenjo dapat memahami pentingnya pencegahan kekerasan dan pornografi pada lingkungan sekolah dan sekitarnya.

\section{Kata Kunci :Manajemen Pengendalian, Pencegahan Kekerasan, Pornografi.}

\section{PENDAHULUAN}

Pendidikan merupakan salah satu faktor yang sangat penting bagi upaya kemajuan suatu bangsa. Sebab pendidikan bertugas untuk meningkatkan sumber daya manusia yang memiliki pengetahuan, melatih keterampilan serta menanamkan sikap dan prilaku yang baik dalam kehidupan berbangsa dan bernegara.

Fenomena yang sering sekali terjadi tindakan kekerasan yang di alami oleh kalangan remaja baik itu berupa tawuran atau kekerasan yang menimpa mereka secara fisik atau psikis dalam permainan, pergaulan atau rumah tangga. Kekerasan yang terjadi di kalangan remaja tidak saja menjadikan remaja sebagai korban kekerasan tapi juga sangat memungkinkan remaja menjadi pelaku dari tindakan kekerasan tersebut. Selain itu remaja juga sangat mudah menjadi sasaran propaganda pornografi baik melalui media social, internet ataupun melalui aktifitas sosial dan kegiatan komunitas. Oleh karena itu remaja atau siswa perlu dibekali dengan manajemen pengendalian diri dan pencegahan terhadap kekerasan dan pornografi.

Sasaran kegiatan Pengabdian kepada masyarakat (PKM) ini adalah denganmengajak siswa-siswi SMPN 2 Tenjo Bogor, untuk mengikuti "Penyuluhan Manajemen Pengendalian, Pencegahan Kekerasan Dan Pornografi Pada Siswa SMPN 2 Tenjo Kabupaten Bogor"
\end{abstract}




\section{RUMUSAN MASALAH}

Berdasarkan latar belakang diatas dapat dirumuskan permasalahan sebagai berikut : Bagaimanamereka dapat mengendalikan dan mencegah aksi pornografi pada siswa-siswi SMPN 2 Tenjo Kabupaten Bogor?

\section{TUJUAN}

Tujuan yang ingin dicapai dalam kegiatan ini adalah : Agar siswa-siswi dapat mengendalikan dan menecgah aksi pornografi dengan penyuluhan yang di berikan oleh Dosen-dosen Universitas Pamulang.

\section{KEGIATAN}

Sasaran dari program Pengabdian Masyarakat yang akan kami lakukan ini adalah siswa-siswi SMPN 2 Tenjo Kabupaten Bogor, dengan jumlah peserta penyuluah kurang lebih 60 orang.

Adapun pelaksanan dari kegiatan adalah sebagai berikut:

$\begin{array}{ll}\text { Hari } & : \text { Selasa - Rabu } \\ \text { Tanggal/Bulan } & : \text { 27 - 28 Maret 2018 } \\ \text { Waktu } & : \text { Pukul 10.00 - 16.00 WIB } \\ \text { Tempat } & : \text { SMPN 2 Tenjo Desa Tapos Kecamatan Tenjo Kabupaten } \\ & \text { Bogor }\end{array}$

\section{APLIKASI}

\section{A. Kekerasan}

Anak adalah tumpuan dan harapan orang tua. Anak jugalah yang akan menjadi penerus bangsa ini. Sedianya, wajib dilindungi maupun diberikan kasih sayang. Namun fakta berbicara lain. Maraknya kasus kekerasan pada anak sejak beberapa tahun ini seolah membalikkan pendapat bahwa anak perlu dilindungi. Begitu banyak anak yang menjadi korban kekerasan keluarga, lingkungan maupun masyarakat dewasa ini.

Pasal 4 UUPA menyatakan bahwa "Setiap anak berhak atas kelangsungan hidup, tumbuh, dan berkembang serta berhak atas perlindungan dari kekerasan dan diskriminas". Namun apakah pasal tersebut sudah dilaksanakan dengan benar? Seperti yang kita tahu bahwa Indonesia masih jauh dari kondisi yang disebutkan dalam pasal tersebut.

Berbagai jenis kekerasan diterima oleh anak-anak, seperti kekerasan verbal, fisik, mental maupun pelecehan seksual. Ironisnya pelaku kekerasan terhadap anak biasanya adalah orang yang memiliki hubungan dekat dengan si anak, seperti keluarga.

Kondisi ini amatlah memprihatinkan, namun bukan berarti tidak ada penyelesaiannya. Perlu koordinasi yang tepat di lingkungan sekitar anak terutama pada lingkungan keluarga untuk mendidik anak tanpa menggunakan kekerasan, 
menyeleksi tayangan televisi maupun memberikan perlindungan serta kasih sayang agar anak tersebut tidak menjadi anak yang suka melakukan kekerasan nantinya.

Tentunya kita semua tidak ingin negeri ini dipimpin oleh pemimpin bangsa yang menyelesaikan kekerasan terhadap rakyatnya.

\section{Pengertian Kekerasan.}

Kekerasan adalah tindakan agresi dan pelanggaran yang menyebabkan penderitaan dan menyakiti orang lain (Kekerasan juga meliputi ancaman, dan tindakan yang bisa mengakibatkan luka dan kerugian, tekanan fisik, perasaan, pikiran, yang merugikan kesehatan dan mental.)

\section{Penyebabnya Kekerasan}

Lemahnya pengawasan orang tua terhadap anak dalam menonton tv, bermain dll. Hal ini bukan berarti orang tua menjadi diktator/over protective, namun maraknya kriminalitas di negeri ini membuat perlunya meningkatkan kewaspadaan terhadap lingkungan sekitar.

a. Kemiskinan keluarga (banyak anak).

b. Keluarga pecah (Broken Home) akibat perceraian, ketiadaan Ibu dalam jangka panjang..

c. Kondisi lingkungan yang buruk, keterbelakangan

d. Penggunaan Waktu Luang yang salah.

\section{Jenis-jenis Kekerasan yang Sering Diterima Anak}

a. Kekerasan Fisik

Bentuk kekerasan seperti ini mudah diketahui karena akibatnya bisa terlihat pada tubuh korban Kasus physical abuse: persentase tertinggi usia 0-5 tahun (32.3\%) dan terendah usia 13-15 tahun (16.2\%). Kekerasan biasanya meliputi memukul, mencekik, menempelkan benda panas ke tubuh korban dan lain-lainnya. Dampak dari kekerasan seperti ini selain menimbulkan luka dan trauma pada korban, juga seringkali membuat korban meninggal

b. Kekerasan secara Verbal

Bentuk kekerasan seperti ini sering diabaikan dan dianggap biasa atau bahkan dianggap sebagai candaan. Kekerasaan seperti ini biasanya meliputi hinaan, makian, maupun celaan. Dampak dari kekerasaan seperti ini yaitu anak jadi belajar untuk mengucapkan kata-kata kasar, tidak menghormati orang lain dan juga bisa menyebabkan anak menjadi rendah diri.

c. Kekerasan secara Mental

Bentuk kekerasan seperti ini juga sering tidak terlihat, namun dampaknya bisa lebih besar dari kekerasan secara verbal. Kekerasaan seperti ini meliputi pengabaian orang tua terhadap anak yang membutuhkan perhatian, teror, celaan, maupun sering membandingbandingkan hal-hal dalam diri anak tersebut dengan yang lain, bisa menyebabkan mentalnya menjadi lemah. Dampak kekerasan seperti ini 
yaitu anak merasa cemas, menjadi pendiam, belajar rendah diri, hanya bisa iri tanpa mampu untuk bangkit.

d. Kekerasan secara seksual

Bentuk kekerasan seperti ini yaitu pelecehan, pencabulan maupun pemerkosaan. Dampak kekerasan seperti ini selain menimbulkan trauma mendalam, juga seringkali menimbulkan luka secara fisik.

\section{Usaha pencegahan kekerasan di Sekolah:}

Sekolah/Guru harus mengetahui penyebab perilaku tindak kekerasan di sekolah Anda

a. Guru jangan memberikan penghakiman, tetapi melakukan percakapan nyata dengan anak-anak

b. Gunakan struktur kepemimpinan yang sudah ada dalam komunitas siswa, Sehingga siswa merasa bahwa mereka memiliki suara dan pengaruh di sekolah,

c. Memecah KLIK sehingga kelompok yang merugikan tidak berkembang di sekolah

d. Bentuk Bimbingan Teman sebaya

e. Meningkatkan kegiatan Extrakurikuler

\section{B. Pornografi}

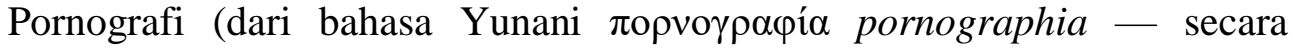
harafiah tulisan tentang atau gambar tentang pelacur) (kadang kala juga disingkat menjadi "porn," "pr0n," atau "porno") adalah penggambaran tubuh manusia atau perilaku seksualitas manusia secara terbuka (eksplisit) dengan tujuan membangkitkan berahi (gairah seksual). Pornografi berbeda dari erotika. Dapat dikatakan, pornografi adalah bentuk ekstrem/vulgar dari erotika. Erotika sendiri adalah penjabaran fisik dari konsep-konsep erotisme. Kalangan industri pornografi kerap kali menggunakan istilah erotika dengan motif eufemisme namun mengakibatkan kekacauan pemahaman di kalangan masyarakat umum.

Pornografi dapat menggunakan berbagai media - teks tertulis maupun lisan, foto-foto, ukiran, gambar, gambar bergerak (termasuk animasi), dan suara seperti misalnya suara orang yang bernapas tersengal-sengal. Film porno menggabungkan gambar yang bergerak, teks erotik yang diucapkan dan/atau suara-suara erotik lainnya, sementara majalah seringkali menggabungkan foto dan teks tertulis. Novel dan cerita pendek menyajikan teks tertulis, kadang-kadang dengan ilustrasi. Suatu pertunjukan hidup pun dapat disebut porno.

\section{Istilah}

Dalam pengertian aslinya, pornografi secara harfiah berarti "tulisan tentang

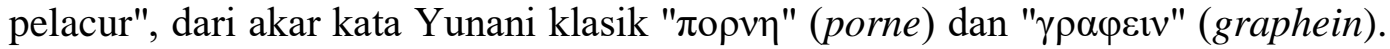
Mulanya adalah sebuah eufemisme dan secara harafiah berarti '(sesuatu yang) dijual.' Kata ini berasal dari dari istilah Yunani untuk orang-orang yang mencatat "pornoai", atau pelacur-pelacur terkenal atau yang mempunyai kecakapan tertentu dari Yunani kuno. Pada masa modern, istilah ini diambil oleh para ilmuwan sosial 
untuk menggambarkan pekerjaan orang-orang seperti Nicholas Restif dan William Acton, yang pada abad ke-18 dan 19 menerbitkan risalah-risalah yang mempelajari pelacuran dan mengajukan usul-usul untuk mengaturnya. Istilah ini tetap digunakan dengan makna ini dalam Oxford English Dictionary hingga 1905.

Belakangan istilah digunakan untuk publikasi segala sesuatu yang bersifat seksual, khususnya yang dianggap berselera rendah atau tidak bermoral, apabila pembuatan, penyajian atau konsumsi bahan tersebut dimaksudkan hanya untuk membangkitkan rangsangan seksual. Sekarang istilah ini digunakan untuk merujuk secara seksual segala jenis bahan tertulis maupun grafis. Istilah "pornografi" seringkali mengandung konotasi negatif dan bernilai seni yang rendahan, dibandingkan dengan erotika yang sifatnya lebih terhormat. Istilah eufemistis seperti misalnya film dewasa dan video dewasa biasanya lebih disukai oleh kalangan yang memproduksi materi-materi ini.

Meskipun demikian, definisi pornografi sangat subjektif sifatnya. Karyakarya yang umumnya diakui sebagai seni seperti misalnya patung "Daud" karya Michelangelo dianggap porno oleh sebagian pihak.

\section{Sejarah}

Pornografi mempunyai sejarah yang panjang. Karya seni yang secara seksual bersifat sugestif dan eksplisit sama tuanya dengan karya seni yang menampilkan gambar-gambar yang lainnya. Foto-foto yang eksplisit muncul tak lama setelah ditemukannya fotografi. Karya-karya film yang paling tuapun sudah menampilkan gambar-gambar telanjang maupun gambaran lainnya yang secara seksual bersifat eksplisit.

Manusia telanjang dan aktivitas-aktivitas seksual ditampilkan dalam sejumlah karya seni paleolitik (mis. patung Venus), namun tidak jelas apakah tujuannya adalah membangkitkan rangsangan seksual. Sebaliknya, gambar-gambar itu mungkin mempunyai makna spiritual. Ada sejumlah lukisan porno di temboktembok reruntuhan bangunan Romawi di Pompeii. Salah satu contoh yang menonjol adalah gambar tentang sebuah bordil yang mengiklankan berbagai pelayanan seksual di dinding di atas masing-masing pintu. Di Pompeii orang pun dapat menjumpai gambaran zakar dan buah zakar yang ditoreh di sisi jalan, menunjukkan jalan ke wilayah pelacuran dan hiburan, untuk menunjukkan jalan kepada para pengunjung (lihat Seni erotik di Pompeii). Para arkeolog di Jerman melaporkan pada April 2005 bahwa mereka telah menemukan apa yang mereka yakini sebagai sebuah gambaran tentang adegan porno yang berusia 7.200 tahun yang melukiskan seorang laki-laki yang sedang membungkuk di atas seorang perempuan dalam cara yang memberikan kesan suatu hubungan seksual. Gambaran laki-laki itu diberi nama Adonis von Zschernitz.

Buku-buku komik porno yang dikenal sebagai kitab suci Tijuana mulai muncul di AS pada tahun 1920-an. Pada paruhan kedua abad ke-20, pornografi di Amerika Serikat berkembang dari apa yang disebut "majalah pria" seperti Playboy dan Modern Man pada 1950-an. Majalah-majalah ini menampilkan perempuan yang telanjang atau setengah telanjang perempuan, kadang-kadang seolah-olah sedang melakukan masturbasi, meskipun alat kelamin mereka ataupun bagian- 
bagiannya tidak benar-benar diperlihatkan. Namun pada akhir 1960-an, majalahmajalah ini, yang pada masa itu juga termasuk majalah Penthouse, mulai menampilkan gambar-gambar yang lebih eksplisit, dan pada akhirnya pada 1990an, menampilkan penetrasi seksual, lesbianisme dan homoseksualitas, seks kelompok, masturbasi, dan fetishes.

Film-film porno juga hampir sama usianya dengan media itu sendiri. Menurut buku Patrick Robertson, Film Facts, "film porno yang paling awal, yang dapat diketahui tanggal pembuatannya adalah $A L^{\prime} E c u$ d'Or ou la bonne auberge", yang dibuat di Prancis pada 1908. Jalan ceritanya menggambarkan seorang tentara yang kelelahan yang menjalin hubungan dengan seorang perempuan pelayan di sebuah penginapan. El Satario dari Argentina mungkin malah lebih tua lagi. Film ini kemungkinan dibuat antara 1907 dan 1912. Robertson mencatat bahwa "film-film porno tertua yang masih ada tersimpan dalam Kinsey Collection di Amerika. Sebuah film menunjukkan bagaimana konvensi-konvensi porno mula-mula ditetapkan. Film Jerman Am Abend (sekitar 1910) adalah, demikian tulis Robertson, "sebuah film pendek sepuluh menit yang dimulai dengan seorang perempuan yang memuaskan dirinya sendiri di kamarnya dan kemudian beralih dengan menampilkan dirinya sedang berhubungan seks dengan seorang laki-laki, melakukan fellatio dan penetrasi anal." (Robertson, hlm. 66)

Banyak film porno seperti itu yang dibuat dalam dasawarsa-dasawarsa berikutnya, namun karena sifat pembuatannya dan distribusinya yang biasanya sembunyi-sembunyi, keterangan dari film-film seperti itu seringkali sulit diperoleh.

Mona (juga dikenal sebagai Mona the Virgin Nymph), sebuah film 59-menit 1970 umumnya diakui sebagai film porno pertama yang eksplisit dan mempunyai plot, yang diedarkan di bioskop-bioskop di AS. Film ini dibintangi oleh Bill Osco dan Howard Ziehm, yang kemudian membuat film porno berat (atau ringan, tergantung versi yang diedarkan), dengan anggaran yang relatif tinggi, yaitu film Flesh Gordon.

Film tahun 1971 The Boys in the Sand dapat disebutkan sebagai yang "pertama" dalam sejumlah hal yang menyangkut pornografi. Film ini umumnya dianggap sebagai film pertama yang menggambarkan adegan porno homoseksual. Film ini juga merupakan film porno pertama yang mencantumkan nama-nama pemain dan krunya di layar (meskipun umumnya menggunakan nama samaran). Ini juga film porno pertama yang membuat parodi terhadap judul film biasa (judul film ini The Boys in the Band). Dan ini adalah film porno kelas $\mathrm{X}$ pertama yang dibuat tinjauannya oleh New York Times.

\section{Teknologi dan pornografi}

Pornografi yang diedarkan secara massal sama tuanya dengan mesin cetak sendiri. Hampir bersamaan dengan penemuan fotografi, teknik ini pun digunakan untuk membuat foto-foto porno. Bahkan sebagian orang mengatakan bahwa pornografi telah menjadi kekuatan yang mendorong yang mendorong teknologi dari mesin cetak, melalui fotografi (foto dan gambar hidup) hingga video, TV satelit dan internet. Seruan-seruan untuk mengatur atau melarang teknologi-teknologi ini telah sering menyebutkan pornografi sebagai dasar keprihatinannya. 
Selama sejarahnya, kamera film juga telah digunakan untuk membuat pornografi, dan dengan munculnya perekam kaset video rumahan, industri film porno pun mengalami perkembangan besar-besaran dan melahirkan bintangbintang "film dewasa" seperti Ginger Lynn, Christy Canyon, dan Traci Lords (belakangan diketahui usianya di bawah usia legal, yaitu 18 tahun, pada saat membuat sebagian besar dari film-filmnya). Orang kini dapat menonton film porno dengan leluasa dalam privasi rumahnya sendiri, ditambah dengan pilihan yang lebih banyak untuk memuaskan fantasi dan fetishnya.

Ditambah dengan hadirnya kamera video yang murah, orang kini mempunyai sarana untuk membuat filmnya sendiri, untuk dinikmati sendiri atau bahkan untuk dijual dan memperoleh keuntungan.

Ada yang berpendapat bahwa Sony Betamax kalah dalam perang format dari VHS (dalam menjadi sistem rekam/tonton video di rumah) karena industri video film biru memilih VHS ketimbang sistem Sony yang secara teknis lebih unggul. Upaya-upaya inovasi lainnya muncul dalam bentuk video interaktif yang memungkinkan pengguna memilih variabel-variabel seperti sudut kamera berganda, penutup berganda (mis. "Devil in the Flesh", 1999), dan isi DVD untuk komputer saja.

Para produsen film erotik diramalkan akan memainkan peranan penting dalam menentukan standar DVD yang akan dating. Kelengkapan (outfit) yang besar cenderung mendukung Cakram cahaya biru yang memiliki kapasitas tinggi, sementara kelengkapan yang kecil umumnya lebih mendukung HD-DVD yang tidak begitu mahal. Menurut sebuah artikel Reuter 2004 "Industri bermilyar-milyar dolar ini menerbitkan sekitar 11.000 judul dalam bentuk DVD setiap tahunnya, memberikannya kekuatan yang sangat besar untuk memengaruhi pertempuran antara kedua kelompok studio dan perusahaan teknologi yang saling bersaing untuk menetapkan standar untuk generasi berikutnya"

Sejumlah pornografi dihasilkan melalui manipulasi digital dalam programprogram editor gambar seperti Adobe Photoshop. Praktik ini dilakukan dengan membuat perubahan-perubahan kecil terhadap foto-foto untuk memperbiaki penampilan para modelnya, seperti misalnya menyingkirkan cacat pada kulit, memperbaiki cahaya dan kontras fotonya, hingga perubahan-perubahan besar dalam bentuk membuat photomorph dari makhluk-makhluk yang tidak pernah ada seperti misalnya gadis kucing atau gambar-gambar dari para selebriti yang bahkan mungkin tidak pernah memberikan persetujuannya untuk ditampilkan menjadi film porno.

Manipulasi digital membutuhkan foto-foto sumber, tetapi sejumlah pornografi dihasilkan tanpa aktor manusia sama sekali. Gagasan tentang pornografi yang sepenuhnya dihasilkan oleh komputer sudah dipikirkan sejak dini sebagai salah satu daerah aplikasi yang paling jelas untuk grafik komputer dan pembuatan gambar tiga dimensi.

Pembuatan gambar-gambar lewat komputer yang sangat realistik menciptakan dilema-dilema etika baru. Ketika gambar-gambar khayal tentang penyiksaan atau pemerkosaan disebarkan secara luas, para penegak hukum 
menghadapi kesulitan-kesulitan tambahan untuk menuntut gambar-gambar otentik yang menampilkan perbuatan kriminal, karena kemungkinan gambar-gambar itu hanyalah gambar sintetik. Keberadaan foto-foto porno palsu dari para selebriti memperlihatkan kemungkinan untuk menggunakan gambar-gambar palsu untuk melakukan pemerasan atau mempermalukan siapapun yang difoto atau difilmkan, meskipun ketika kasus-kasus itu menjadi semakin lazim, pengaruhnya kemungkinan akan berkurang. Akhirnya, generasi gambar-gambar yang sama sekali bersifat sintetik, yang tidak merekam peristiwa-peristiwa yang sesungguhnya, menantang kritik-kritik konvensional terhadap pornografi.

Hingga akhir 1990-an pornografi yang dihasilkan melalui manipulasi digital belum dapat dihasilkan dengan murah. Pada awal 2000-an kegiatan ini semakin berkembang, ketika perangkat lunak untuk pembuatan model dan animasi semakin maju dan menghasilkan kemampuan-kemampuan yang semakin tinggi pada komputer. Pada tahun 2004, pornografi yang dihasilkan lewat komputer gambarnya melibatkan anak-anak dan hubungan seks dengan tokoh fiksi seperti misalnya Lara Croft sudah dihasilkan pada tingkat yang terbatas. Terbitan Playboy pada Oktober 2004 menampilkan foto-foto telanjang dada dari tokoh permainan video BloodRayne.

\section{Internet}

Dengan munculnya internet, pornografi pun semakin mudah didapat. Sebagian dari pengusaha wiraswasta internet yang paling berhasil adalah mereka

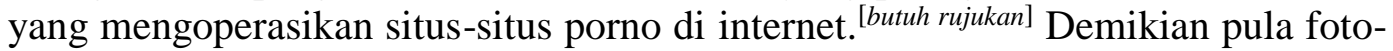
foto konvensional ataupun video porno, sebagian situs hiburan permainan video "interaktif". Karena sifatnya internasional, internet memberikan sarana yang mudah kepada konsumen yang tinggal di negara-negara di mana keberadaan pornografi dilarang sama sekali oleh hukum, atau setidak-tidaknya mereka yang tidak perlu memperlihatkan bukti usia, dapat dengan mudah mendapatkan bahan-bahan seperti itu dari negara-negara lain di mana pornografi legal atau tidak mengakibatkan tuntutan hukum. Lihat pornografi internet.

Biaya yang murah dalam penggandaan dan penyebaran data digital meningkatkan terbentuknya kalangan pribadi orang-orang yang tukar-menukar pornografi. Dengan munculnya aplikasi berbagi file peer-to-peer seperti Kazaa, tukar-menukar pornografi telah mencapai rekor yang baru. Pornografi gratis tersedia secara besar-besaran dari para pengguna lainnya dan tidak lagi terbatas pada kelompok-kelompok pribadi. Pornografi gratis dalam jumlah besar di internet juga disebarkan dengan tujuan-tujuan pemasaran, untuk menggalakkan para pelanggan yang membeli program bayaran.

Sejak akhir tahun 1990-an, "porno dari masyarakat untuk masyarakat" tampaknya telah menjadi kecenderungan baru. Kamera digital yang murah, perangkat lunak yang kian berdaya dan mudah digunakan, serta akses yang mudah ke sumber-sumber bahan porno telah memungkinkan pribadi-pribadi untuk membuat dan menyebarkan bahan-bahan porno yang dibuat sendiri atau dimodifikasi dengan biaya yang sangat murah dan bahkan gratis. 
Di internet, pornografi kadang-kadang dirujuk seagai prOn yaitu plesetan dari pOrn - porno yang ditulis dengan angka nol. Salah satu teori tentang asal usul ejaan ini ialah bahwa ini adalah siasat yang digunakan untuk mengelakkan penyaring teks dalam program-program pesan pendek atau ruang obrol.

Menurut Google, setiap hari terjadi 68 juta pencarian dengan menggunakan kata "porno" atau variasinya. Status hukum pornografi sangat berbeda-beda. Kebanyakan negara mengizinkan paling kurang salah satu bentuk pornografi. Di beberapa negara, pornografi ringan dianggap tidak terlalu mengganggu hingga dapat dijual di toko-toko umum atau disajikan di televisi. Sebaliknya, pornografi berat biasanya diatur ketat. Pornografi anak dianggap melanggar hukum di kebanyakan negara, dan pada umumnya negara-negara mempunyai pembatasan menyangkut pornografi yang melibatkan kekerasan atau binatang.

Sebagian orang, termasuk produser pornografi Larry Flynt dan penulis Salman Rushdie, mengatakan bahwa pornografi itu penting bagi kebebasan dan bahwa suatu masyarakat yang bebas dan beradab harus dinilai dari seberapa jauh mereka bersedia menerima pornografi.

Kebanyakan negara berusaha membatasi akses anak-anak di bawah umur terhadap bahan-bahan porno berat, misalnya dengan membatasi ketersediaannya hanya pada toko buku dewasa, hanya melalui pesanan lewat pos, lewat saluransaluran televisi yang dapat dibatasi orang tua, dll. Biasanya toko-toko porno membatasi usia orang-orang yang masuk ke situ, atau kadang-kadang barangbarang yang disajikan ditutupi sebagian atau sama sekali tidak terpampang. Yang lebih lazim lagi, penyebaran pornografi kepada anak-anak di bawah umur dianggap melanggar hukum. Namun banyak dari usaha-usaha ini ternyata tidak mampu membatasi ketersediaan pornografi karena akses yang cukup terbuka terhadap pornografi internet.

\section{STRATEGI}

Dari identifikasi tersebut melalui teknik seminar, simulasi dan pendekatan persuasif kepada peserta siswa -siswi SMPN 2 Tenjo, diberikan pengetahuan mengenai bahaya kekerasan dan pornografi yang sering terjadi di sekitar peserta serta diberikan penyuluhan bagaimana cara mengatasi hal tersebut dengan manajemen pengendalian, pencegahan kekerasan dan pornografi

\section{PENUTUP}

Dengan ada nya kegiatan ini menjadikan para peserta siswa -siswi SMPN 2 Tenjo dapat memahami pentingnya pencegahan kekerasan dan pornografi pada lingkungan sekolah dan sekitarnya.

Dengan pengabdian ini siswa -siswi SMPN 2 Tenjo dapat mengatasi segala macam ancaman kekerasan dan pornografi sehingga membantu meningkatkan prestasi dalam hal akademik untuk kehidupan mereka pada masa yang akan datang. 
DAFTAR REFERENSI

https://id.wikipedia.org/wiki/Pornografi

https://pendidikan.m2indonesia.com/smp/smpn-2-tenjo-kab-bogor-20200648.htm https://ideguru.wordpress.com/2010/04/25/faktor-faktor-penyebab-kekerasanpada-siswa/

\section{DOKUMENTASI FOTO KEGIATAN}
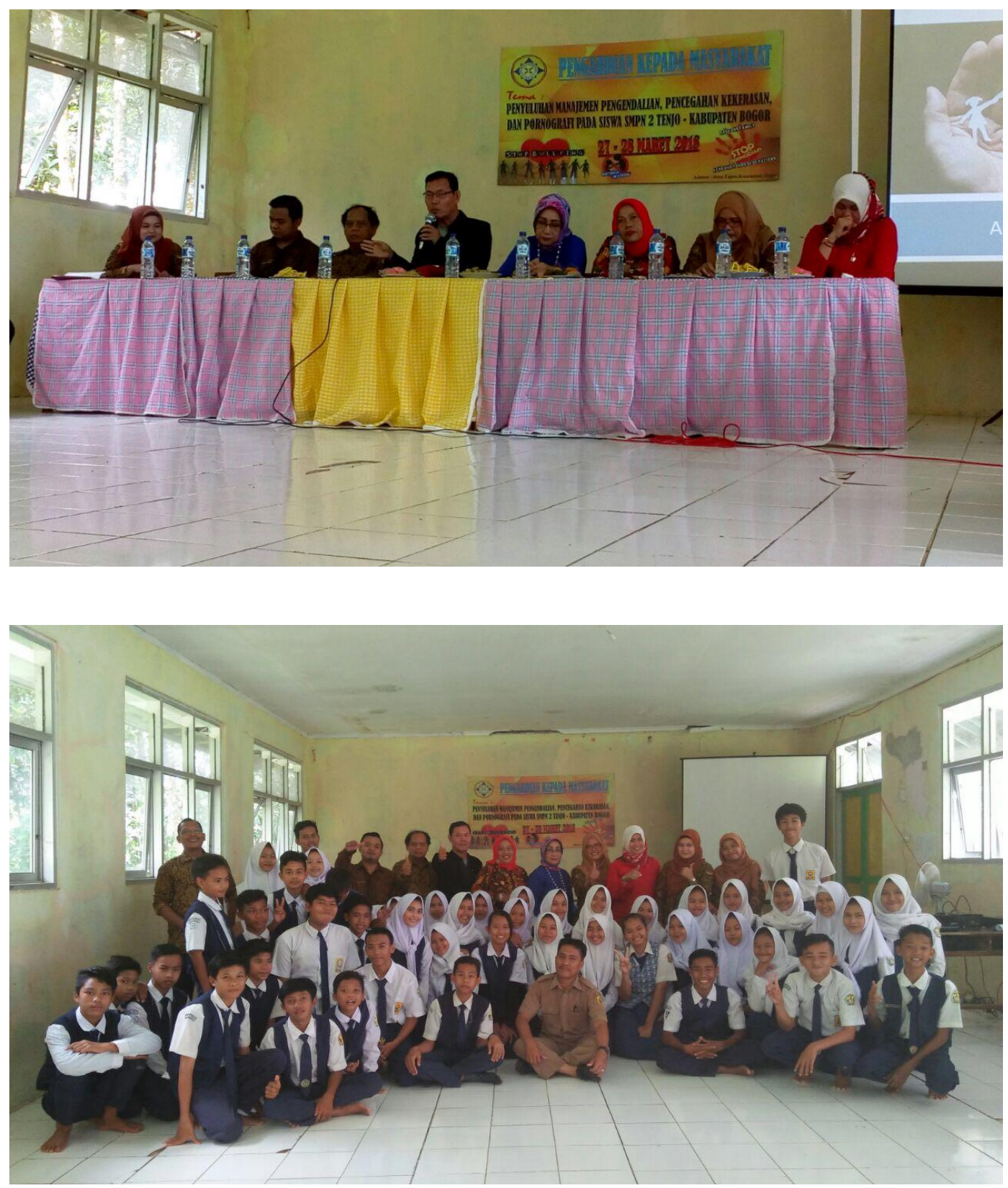